\title{
CYTOSPORA CANKER DEVELOPMENT ON ASPEN IN RESPONSE TO NITROGEN FERTILIZATION
}

\author{
by Susan Burks, ${ }^{1}$ William R. Jacobi, ${ }^{2}$ and Gary A. McIntyre ${ }^{2}$
}

\begin{abstract}
The effect of nitrogen fertilization on Cytospora canker development in aspen (Populus tremuloides) was examined in a greenhouse hydroponic system. Aspen trees grown in rock wool or sand were watered with 1 of 5 nitrogen treatments: $0,55,111,185$, or $333 \mathrm{mg} / \mathrm{L}$ nitrogen as $\left(\mathrm{NH}_{4}\right)_{2} \mathrm{NO}_{3}$. After $6 \mathrm{wk}$, trees were inoculated with 2 isolates of Cytospora chrysosperma in separate wounds. Canker length and width were measured every 2 wk for $6 \mathrm{wk}$, beginning the 2nd week after inoculation. To assess the effect of prolonged nutrient treatment on canker development, a subset of the original trees was selected to receive treatments for 2 growing seasons, with inoculations at 6 wk after treatments were begun in the 2 nd season. Nitrogen deficiency $(0 \mathrm{mg} / \mathrm{L})$ contributed to significantly larger cankers in 1 of 4 trials run for 1 growing season and in the 2 trials carried out for 2 growing seasons $(P=0.00-0.006)$. Canker sizes on trees treated with the other nitrogen rates were not significantly different from each other. Large cankers formed on trees treated with the abnormally high rate $(333 \mathrm{ppm})$, but the differences were not significant from the other nitrogen treatments. Thus, nitrogen deficiencies increase the likelihood of canker expansion, while proper nutrient management allows aspen to defend against canker expansion induced by Cytospora fungi.
\end{abstract}

Aspen trees (Populus tremuloides) are used commonly in western U.S. landscapes, but they are susceptible to infection by several cankerinducing pathogens, including Cytospora chrysosperma (Hinds 1985). Cytospora canker is common on many willows and other poplars. Although this disease is stable in native or naturalized areas, canker incidence seems to be increasing in maintained urban landscapes.

Incidence and expansion of cankers caused by $C$. chrysosperma is favored by conditions that stress host trees. These stresses include drought, wounding, excess soil salts, and severe defoliation (Bloomberg 1962; Schoeneweiss 1967; Hinds 1985; Guyon 1996; Mclntyre et al. 1996). Cytospora canker is associated with transplant stress, pruning wounds, insect damage, sunscald, and weak branches (Bloomberg 1962; Neely 1984; Hinds 1985; Guyon 1996; Mclntyre et al. 1996 ). Little is known about the effect of soil ni- trogen availability on resistance or susceptibility of aspen to infection by $C$. chrysosperma.

Turf competition can influence nitrogen availability and tree growth (Bailey and Gupta 1973; Messenger 1976; Khatamian et al. 1984; Neely 1984). When turf limits only the nutrient availability-without affecting water availabilityapplied nitrogen will increase tree growth (Smith 1978; van de Werken 1981; Khatamian et al. 1984; Neely 1984; Hansen et al. 1988). However, excess nitrogen applied to trees can slow growth and create stress (Fisher et al. 1981; Khatamian et al. 1984). Although little is known about the nutritional needs of trees, their requirements are generally less than those of turfgrass species (Feucht and Butler 1988). Thus, fertilizer regimes designed for turf may impact tree health.

Soil nitrogen levels can influence health and development of both pathogenic microbes and host plants and thereby affect the kind and severity of disease expression (Huber and Watson 1974; Huber 1980a, 1980b). Excess nitrogen can increase plant succulence and increase pathogen nutrition (Dinus and Schmidtling 1971; Suzuki 1973; Rowan 1977; Bavaresco and Eibach 1987; Cadic et al. 1987), whereas deficiency can stress the host and decrease host defense capabilities (Bagga and Smalley 1974; Matson and Waring 1984). Unfortunately, little is known about the effect of nitrogen deficiency or excess on aspen's ability to defend against Cytospora canker fungi and/or disease development. Thus, our objective for this study was to determine if Cytospora canker expansion in aspen was affected by nitrogen deficiency or excess.

\section{Materials and Methods}

Three experiments with 2 trials each were conducted to learn how nitrogen fertilization affected canker development on aspen. Two experimentsexperiment 1 in year 1 and experiment 2 in year 
2-exposed aspens to various levels of nitrogen for 1 growing season. A 3rd experiment exposed aspens to the nitrogen treatments for 2 growing seasons. Trees were grown in rock wool during the 1st year (experiment 1 and 1st year of experiment 3 ) and in washed masonry sand for the 2nd year's experiments (experiment 2 and 2 nd year of experiment 3) because rock wool used in the 1styear trials apparently retained excess moisture, which is unsuitable for aspen growth.

Plant material. For experiment 1, 3-to-4-yr-old potted seedling aspens, approximately $2 \mathrm{~cm}(0.8$ in.) diameter above the root flare, were repotted in June into rock wool in 18.9-L (5 gal) black plastic pots. Original potting mix was removed by washing roots before repotting. These trees were allowed to become established for 6 wk before receiving nitrogen treatments, during which time the trees were watered weekly with deionized water. Because of a high rate of mortality following transplanting, half the trees in experiment 1 , trial 2 were replaced. Replacement trees had 2 wk of establishment before treatments.

For experiment 2, a 2nd set of aspen trees (from the same source and of the same size and age as those used in experiment 1) was repotted in sand into 18.9-L (5 gal) black plastic pots in April. These trees were allowed to become established for 4 wk before nitrogen treatments were started in May.

For experiment 3 , trees from experiment 1 were held over for a 2nd year and repotted in mid-February using washed masonry sand. Only those trees were used that either had not been inoculated or that had wounds sufficiently callused to allow reinoculation. $A$ tree received the same (or the next higher) nitrogen treatment in year 2 as it did in year 1 . These trees were allowed to become established for $11 \mathrm{wk}$ before nitrogen treatments were applied in May. Greenhouse conditions ranged from $40 \%$ to $90 \%$ relative humidity and from $15^{\circ} \mathrm{C}$ to $34^{\circ} \mathrm{C}\left(59^{\circ} \mathrm{F}\right.$ to $\left.93.2^{\circ} \mathrm{F}\right)$.

Fungi. Two pathogenic isolates of $C$. chrysosperma were used. Isolates $91-1$ and 91 2 were obtained in 1990 from a plains cottonwood (Populus sargenti) and a lombardy poplar ( $P$. nigra cv. Italica), respectively, growing in Fort Collins, Colorado. Isolates were transferred to acidified potato-dextrose agar (PDA) and grown for 7 days at $23^{\circ} \mathrm{C}\left(73.4^{\circ} \mathrm{F}\right)$ in the dark before inoculation.

Inoculations. In the 1st year, 5 crushing wounds were made aseptically on each tree through the bark to the xylem with a $13 \mathrm{~mm}$ wide (0.5 in.) cold chisel. In the 2nd year, trees were wounded by removing the bark with a $10 \mathrm{~mm}$ diameter ( 0.4 in.) cork borer. Areas to be wounded were wiped with $95 \%$ ethanol before wounding, and wounding tools were flame sterilized. A 12 $\mathrm{mm}$ diameter (0.45 in.) agar plug of 1 of the 2 isolates was placed on 2 wounds per tree for a total of 4 wounds. The 5 th wound received sterile agar as a control. Immediately after inoculation, wounds were wrapped in wax film. Canker size estimates consisted of length plus width measurements of the discolored bark area around each wound. After the last measurement, isolations utilizing wood and inner bark chips from canker or wound margins were made from $10 \%$ of the inoculated wounds to confirm the presence of the fungus.

Experiment 1. Nutrient solutions with 5 different levels of nitrogen were used as fertilizer treatments in year 1 . These consisted of 0,55 , 111,185 , and $333 \mathrm{mg} / \mathrm{L}(0,2.2,4.4,7.4$, and 13.3 $\mathrm{lb} / \mathrm{gal})$ nitrogen in the form of $\left(\mathrm{NH}_{4}\right)_{2} \mathrm{NO}_{3}$. All other nutrient levels were constant across all treatments within $+10 \%$ of half the rate recommended by Hoagland and Arnon (1950). Trees were fertilized with a drip irrigation system once a week, beginning July 9 and July 30 . Inoculations were made 6 wk after treatments were started. Treatments continued for 6 wk following inoculations for a total of 12 wk or an average of $11.4 \mathrm{~L}$ ( 3 gal) per tree over the course of the experiment. Canker size measurements were made 2 wk after inoculation and were repeated at 4 wk and 6 wk after inoculation. Trees also were flushed weekly with deionized water to prevent salt accumulation. Each trial consisted of 50 trees arranged in a randomized complete-block design with 10 replications. A replicate consisted of 1 tree for each of the 5 nutrient treatments.

One tissue sample for nutrient analysis for each treatment was taken 6 wk after establishment of the 2 trials. Samples consisted of a single 
excised twig, including leaves, petioles, and stem, from the lower crown of each of 5 randomly selected trees per treatment.

Experiments 2 and 3. In experiments 2 and 3 , only 4 nitrogen treatments were used. The 111 $\mathrm{mg} / \mathrm{L}(4.4 \mathrm{lb} / \mathrm{gal})$ nitrogen treatment from the previous season was omitted because leaf nitrogen content and canker size between the 55 and 185 $\mathrm{mg} / \mathrm{L}$ (2.2 and $7.4 \mathrm{lb} / \mathrm{gal}$ ) nitrogen treatments did not differ in the first 2 trials. Trees were placed in randomized complete blocks in the greenhouse. Experiment 2 contained 2 trials, with each trial using 48 new trees-12 trees for each of the 4 nitrogen treatments. Experiment 3 contained 2 trials, with each trial using 32 trees from experiment $1-8$ trees for each of the 4 nitrogen treatments. Treatments for both experiments were initiated in early May. Because of the low waterholding capacity of the sand, nutrient solutions were administered 3 times per week with no flushing with deionized water, for a total average of $30.3 \mathrm{~L}$ (8 gal) per tree over the course of the experiments. Inoculations occurred 47 and 51 days later; canker size measurements began $2 \mathrm{wk}$ after inoculation and were repeated at 4 and 6 wk after inoculation. Trees were rated visually for foliar stress symptoms every 2 wk throughout all trials. Ratings ranged from 1 for healthy green to 5 for dead or leafless trees.

At the end of experiments 2 and $3,50 \%$ of the trees were measured for basal diameter and height, and diameter at the wound. All trees were removed from their pots and the percentage of dead root tissue was determined visually. Roots were then oven dried at $110^{\circ} \mathrm{C}\left(230^{\circ} \mathrm{F}\right)$ and weighed. Live root weight was calculated based on total weight and percentage of dead tissue.

Statistical analysis. To adjust for large variances and skewed data (some cankers expanded much more than others), data were transformed by $\log ^{10}$ and analyzed for variance with SPSS Manova software (1986). Treatment data, based on the last reading of canker size, were analyzed by year, trial, group, block, and isolate over time. Data from experiments 2 and 3 were analyzed with and without covariants of live root tissue dry weight, percentage of dead root tissue, and leaf tissue nitrogen content. Measurements also were analyzed independently with respect to possible treatment effects. The 2 trials in experiments 2 and 3 were combined in the analysis because there were no differences between the trials. Thus, the results are presented as the combined experimental data, not as separate trials.

\section{Results}

Significantly larger cankers $(P=0.006)$ formed on aspen trees receiving no nitrogen than formed on trees receiving 55 to $333 \mathrm{ppm}$ nitrogen in trial 1 of experiment 1 (Figure 1). In the 2 nd trial of experiment 1 , the trend among canker means was the same as in trial 1, but the treatment differences were not significantly different. In experiment 2, cankers on trees receiving no nitrogen for 1 season in the 2 trials were not significantly larger than on trees with nitrogen treatments (Figure 2). However, cankers on trees in experiment 3 (those trees treated for 2 seasons) were significantly $(P=0.001)$ larger on trees receiving no nitrogen (Figure 3 ). Cankers on trees receiving $333 \mathrm{ppm}$ nitrogen in experiments 2 and 3 were large but not signifi-

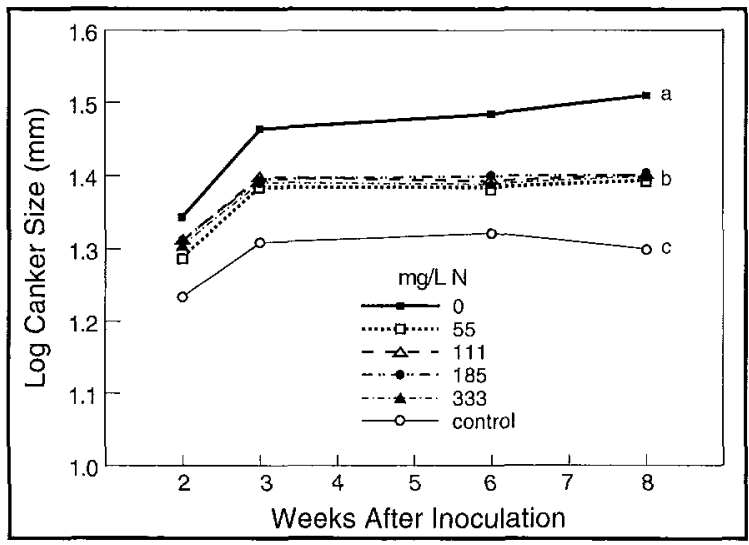

Figure 1. Canker development on aspen treated with various levels of nitrogen during 1 growing season and inoculated with $C$. chrysosperma at the beginning of the same season (experiment 1 , trial 1). Mean canker size consists of canker or wound length plus width, transformed by $\log ^{10}, n$ $=40$. Isolate values were combined. Differing letters denote significant mean differences of last reading by LSD mean separation, $P=0.006$. Control wounds consisted of wounds inoculated with sterile agar. 


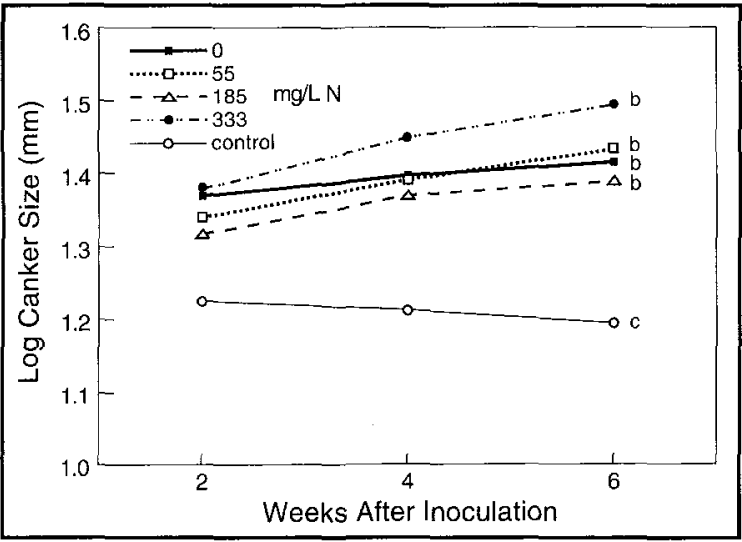

Figure 2. Canker development on aspen receiving various levels of nitrogen for 1 season (experiment 2 , combined trials). Trees were inoculated with $C$. chrysosperma after 6 wk of treatment. Mean canker size consists of canker or wound length plus width transformed by $\log ^{10}, n=96$. Isolate values were combined. Differing letters denote significant mean differences on last reading by LSD mean separation. $P=0.006$. Control wounds consisted of wounds inoculated with sterile agar.

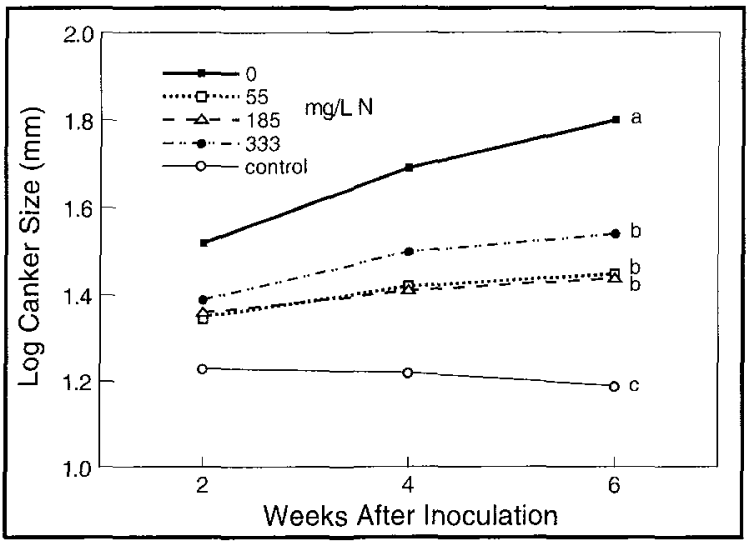

Figure 3. Canker development on aspen receiving various levels of nitrogen for 2 seasons (experiment 3). Trees were inoculated with $C$. chrysosperma during the 2nd season. Mean canker size consists of canker or wound length plus width transformed by $\log ^{10}, n=64$. Isolate values were combined. Differing letters denote significant mean differences on last reading by LSD mean separation. $P=0.006$. Control wounds consisted of wounds inoculated with sterile agar. cantly larger than the cankers on trees exposed to the other nitrogen treatments (Figures 2 and 3 ).

The degree of stress symptoms was not different among treatments or experiments except for more severe symptoms on trees provided with no nitrogen for $2 \mathrm{yr}$ (experiment 3 ).

In experiment 1, the percentage of cankers that expanded ranged from $70 \%$ on trees receiving no nitrogen to $23 \%$ on trees receiving $55 \mathrm{mg} / \mathrm{L}(2.2$ $\mathrm{lb} /$ gal) nitrogen. Overall, $57 \%$ of the cankers across both trials failed to expand. Nonexpanding cankers were not substantially different in size than the control wounds. Thus, expanding cankers on single trees greatly influenced treatment means. In experiments 2 and 3 , the percentage of expanding cankers ranged from $100 \%$ of those on trees receiving no nitrogen to $60 \%$ of those on trees receiving $55 \mathrm{mg} / \mathrm{L}(2.2 \mathrm{lb} / \mathrm{gal})$ nitrogen. Under the highest nitrogen treatment, the percentage of expanding cankers ranged from $2 \%$ to $70 \%$, so there was no correlation with nitrogen treatment. All efforts to isolate the pathogen from inoculated wounds were successful.

Nitrogen levels in aspen tissue increased with increasing levels of nitrogen fertilizer, but not all increases were significantly different from each other (Figure 4). Two covariants-the percentage of dead roots and live root dry weight-were correlated to canker size among trees treated for 1 season ( $P=0.036$ and $P=0.009$, respectively). These correlations, however, explained little of the variation within treatments and had little effect on overall significance levels. Neither of the covariants was correlated with canker size among trees treated for 2 seasons, and no statistical differences were apparent among height and diameter measurements over the range of nitrogen applications.

\section{Discussion}

Cytospora canker size was significantly larger on trees receiving no nitrogen for 2 seasons than on trees receiving nitrogen for the same amount of time. Increased disease severity associated with aspen under nutrient stress parallels that observed in aspen under other stress conditions such as drought, wound, and transplant shock (Bloomberg 


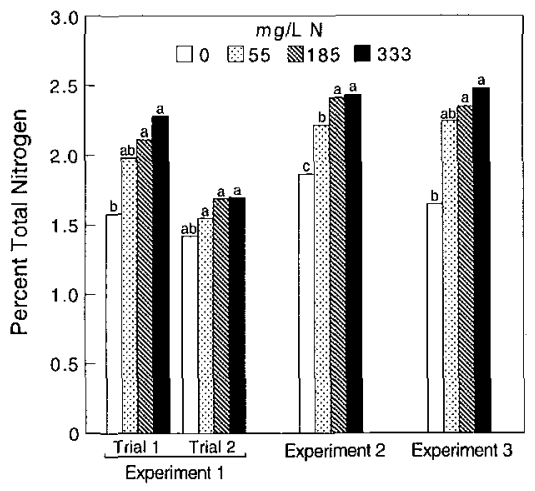

Figure 4. Aspen leaf tissue nitrogen levels in experiment 1 ( 1 season) and in the combined trials of experiment 2 ( 1 season) and 3 ( 2 seasons). Differing letters within a group/trial denote significant mean differences at $P=.05$ using LSD mean separation $\boldsymbol{n}=\mathbf{5}$ per treatment.

1962; Hinds 1985; Guyon 1996; Mclntyre et al. 1996 ). The lack of canker expansion among trees receiving moderate levels of nitrogen suggests that tree resistance mechanisms may involve host response to nutrient deficiencies, rather than fungal stimulation via nutrition. The expansion of cankers at the high level of nitrogen indicates that excess nitrogen may stress aspen, but because this rate is not normal, excess nitrogen is not likely a predisposing stress of aspen.

Cankers on trees receiving no nitrogen for 1 season in trial 2 of experiment 1 and in experiment 2 failed to expand significantly as the cankers did in 1 trial in experiment 1 and in both trials of experiment 3 . This may be the result of residual nitrogen from fertilizations received at the nursery before the initiation of the trials. Trees for the trials were received and potted 2 and 4 $w k$, respectively, before treatment. Apparently, a 2-to-4 wk establishment period followed by a 6wk treatment period is not sufficient for aspen to manifest nutrient response. Based on our results, a minimum period of water-only establishment of 6 to $11 \mathrm{wk}$, followed by a 6 -wk treatment period, appears necessary for reliable responses, while the best response was after treatment for 2 growing seasons.

The failure of aspen cankers to expand in many trials regardless of treatment is most likely a result of trees not being stressed and thus being able to defend against the canker pathogen.

No consistent, significant differences occurred between treatment responses of the 2 isolates of C. chrysosperma, nor were there consistent treatment differences related to root mass. Root weights were expected to relate to canker size because there was so much variation in canker expansion within treatments, but this was not the case. Even though there were root mass differences, these were not related to canker expansion. Unfortunately, root mass does not measure the health of roots, nor does it determine whether the roots are functional or are contributing to drought stress.

We still do not know how long trees can tolerate nitrogen deficiencies without becoming stressed. This research demonstrated that 2 seasons are sufficient to deplete nutrient reserves in young trees. In larger trees, the time necessary for depletion may be different. A larger root system on established trees may facilitate utilization of limited soil nutrients, but a larger crown also may increase the nitrogen depletion rate. Together, the response is unknown. Further research is needed to answer this question.

Treatments in these trials were designed to cover a wide range of nitrogen levels because little work has been done to identify optimal nutrient levels for aspen trees. Levels within this range need to be further tested to establish optimal nitrogen levels so that excess nitrogen is not applied. Until this occurs, fertilization recommendations will continue to be based on rough guesses and extrapolation of data from other nonwoody plant species. An approximate conversion of the rates of nitrogen used in this study to rates applied to turf are $55 \mathrm{mg} / \mathrm{L}=2.2 \mathrm{lb}, 111 \mathrm{mg} /$ $L=4.4 \mathrm{lb}, 185=7.4 \mathrm{lb}$, and $333 \mathrm{mg} / \mathrm{L}=13.3 \mathrm{lb}$ of nitrogen $/ 1,000 \mathrm{ft}^{2}$.

The implications for trees in the field from our results with young aspen are twofold. Prolonged nutrient deficiency may increase disease expression and, given readily available inoculum, may increase disease incidence as well. However, normal nitrogen concentrations in most soils are high enough to prevent predisposing stress in young trees to infection by Cytospora canker 
fungi. Thus, variations in nitrogen content of soil are not likely the reason for the high incidence of Cytospora canker on aspens in landscapes.

Acknowledgments. We recognize the assistance of J.R. zumBrunnen for statistical advice and Earl G. Ruppel and John A. Hendrix for reviewing the manuscript. Funding for this project was through the Colorado Agricultural Experiment Station, journal article number 157451.

\section{Literature Cited}

Bagga, D.K., and E.B. Smalley. 1974. The development of Hypoxylon canker of Populus tremuloides: Role of interacting environmental factors. Phytopathology. 64:658-662.

Bailey, A.W., and R.K. Gupta. 1973. Grass-woody plant relationships. Can. J. Plant Sci. 53:671-676.

Bavaresco, L., and R. Eibach. 1987. Investigations on the influence of $N$ fertilizer on resistance to powdery mildew (Oidium tuckerii), downy mildew (Plasmopara viticola) and on phytoalexin synthesis in different grapevine varieties. Vitis 26:192-200.

Bloomberg, W.J. 1962. Cytospora canker of poplars: Factors influencing the development of the disease. Can. J. Bot. 40:1271-1280.

Cadic, A., F. Lemaire, and J.P. Paulin. 1987. Nitrogen nutrition and susceptibility to fire blight ( $\mathrm{E}$. amylovora) of Pyracantha cv. Mohave: $A$ preliminary study using a hydroponic system. Acta Hort. 217:149-155.

Dinus, R.J., and R.C. Schmidtling. 1971. Fusiform rust in loblolly and slash pines after cultivation and fertilization. USDA. For. Serv. Res. Paper SO-68. $10 \mathrm{pp}$.

Feucht, J.R., and J.D. Butler. 1988. Soils and plant fertility, pp. 13-30. In Landscape Management. Van Nostrand Reinhold Co., New York, NY.

Fisher, R.F., W.S. Garbett, and E.M. Underhill. 1981. Effects of fertilization on healthy and pitch cankerinfected pines. Southern J. App. For. 5:77-79.

Guyon, J.C. 1996. Effects of environmental stress on the development of Cytospora canker on aspen. Plant Dis. 80:1320-1326.

Hansen, E.A., R.A. McLaughlin, and P.E. Pope. 1988. Biomass and nitrogen dynamics of hybrid poplar on two different soils: Implications for fertilization strategy. Can. J. For. Res. 18:223-230.

Hinds, T.E. 1985. Diseases. In DeByle, N.V., and R. R. Winokur (Eds). Aspen: its ecology and management. USDA For. Serv. Gen. Tech. Rprt. RM-119. 283 pp.
Hoagland, D.R., and D.I. Arnon. 1950. The waterculture method for growing plants without soil. Calif. Agric. Exp. Sta. Circu. \#347. Univ. Calif. Berkeley, CA. $32 \mathrm{pp}$.

Huber, D.M. 1980a. The use of fertilizers and organic amendments in the control of plant disease, pp. 357-394. In Pimental, D.D. (Ed). Handbook Series in Agriculture. Sect. CRC Press, Inc., Palm Beach, FL.

Huber, D.M. 1980b. The role of mineral nutrition in defense. In Horsfall, J.G., and Cowling (Eds). Plant Disease: An Advanced Treatise. Academic Press, New York, NY. 5:381-406.

Huber, D.M., and R.D. Watson. 1974. Nitrogen form and plant disease. Annu. Rev. Phytopathol. 12:139-165.

Khatamian, H., J.C. Pair, and R. Carrow. 1984. Effects of turf competition and fertilizer application on trunk diameter and nutrient composition of honeylocust. J. Arboric. 10:156-159.

Matson, P.A., and R.H. Waring. 1984. Effects of nutrient and light limitation on mountain hemlock: Susceptibility to laminated root rot. Ecology. 65:1517-1524.

McIntyre, G.A., W.R. Jacobi, and A.W. Ramaley. 1996. Factors affecting Cytospora canker occurrence on aspen. J. Arboric. 22:229-233.

Messenger, S.A. 1976. Root competition: Grass effects on trees. J. Arboric. 2:229-230.

Neely, D. 1984. Grass competition for $N$ around landscape trees. J. Environ. Hort. 2:86-88.

Rowan, S.J. 1977. Fertilizer-induced changes in susceptibility to Fusiform rust vary among families of slash and loblolly pine. Phytopathology. 67:1280-1284.

Schoeneweiss, D.F. 1967. Susceptibility of weakened cottonwood stems to fungi associated with blackstem. Plant Dis. Rptr. 51:933-935.

Smith, E.M. 1978. Fertilizing trees and shrubs in the landscape. J. Arboric. 4:157-161.

SPSS, Inc. 1986. SPSSX User's Guide. Chicago, IL. $988 \mathrm{pp}$.

Suzuki, K. 1973. Studies on the susceptibility to poplar leaf rust influenced by different nutrient conditions (I): Changes of susceptibility induced by nutrient deficiency. J. Jap. For. Soc. 55:29-34.

van de Werken, H. 1981. Fertilization and other factors enhancing the growth rate of young shade trees. J. Arboric. 7:33-37. 
${ }^{1}$ Missouri Department of Conservation

P.O. Box 180

Jefferson City, MO 65102-0180

${ }^{2}$ Department of Bioagricultural Sciences and Pest Management

Colorado State University

Fort Collins, CO 80523
Zusammenfassung. In einem Gewächshausbewässerungssystem wurden die Auswirkungen von $\mathrm{N}$ Dügung von die Entwicklung des Pappelkrebses (Cytospora chrysosperma) auf Zitterpappelen (Populus tremulus) untersucht. Mit je einer aus fünf $N$-gaben: $0,55,111,185$, und $333 \mathrm{mg} / \mathrm{L} \mathrm{M}$ wurden die Bäume, die auf Steinwolle oder Sand wachsen, behandelt. Nach sechs Wochen wurden die Bäume mit zwei Krebs isolaten in verschiedenen Wunden behandelt. In zwei von drei Versuchen während einer Wachstumsperiode und bei allen Versuchen über zwei Wachstumsperioden führte der N-Mangel zu deutlich größeren Krebswunden. Während aller anderer $N$ behandlungen veränderten sich die Krebswunden nicht signifikant. 